\title{
Impacts of seasonal and regional variability in biogenic VOC emissions on surface ozone in the Pearl River delta region, China
}

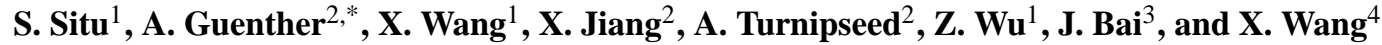 \\ ${ }^{1}$ School of Environmental Science and Engineering, Sun Yat-sen University, Guangzhou, 510275, China \\ ${ }^{2}$ National Center for Atmospheric Research, CO, USA \\ ${ }^{3}$ LAGEO, Institute of Atmospheric Physics, Chinese Academy of Sciences, Beijing, 100029, China \\ ${ }^{4}$ State Key Laboratory of Organic Geochemistry, Guangzhou Institute of Geochemistry, Chinese Academy of Science, \\ Guangzhou 510640, China \\ *now at: Pacific Northwest National Laboratory, Richland WA 99532, USA
}

Correspondence to: X. Wang (eeswxm@mail.sysu.edu.cn)

Received: 29 December 2012 - Published in Atmos. Chem. Phys. Discuss.: 13 March 2013

Revised: 30 October 2013 - Accepted: 1 November 2013 - Published: 5 December 2013

\begin{abstract}
This study investigated the impacts of seasonal and regional variability in biogenic volatile organic compounds (BVOCs) on surface ozone over the Pearl River delta (PRD) region in southern China in 2010 with the WRFChem/MEGAN (Weather Research and Forecasting coupled with Chemistry/Model of Emissions of Gases and Aerosols from Nature) modeling system. Compared to observations in the literature and this study, MEGAN tends to predict reasonable BVOC emissions in summer, but may overestimate isoprene emissions in autumn, even when the local high-resolution land-cover data and observed emission factors of BVOCs from local plant species are combined to constrain the MEGAN BVOC emissions model. With the standard MEGAN output, it is shown that the impact of BVOC emissions on the surface ozone peak is $\sim 3 \mathrm{ppb}$ on average with a maximum of $24.8 \mathrm{ppb}$ over the PRD region in autumn, while the impact is $\sim 10 \mathrm{ppb}$ on average, with a maximum value of $34.0 \mathrm{ppb}$ in summer. The areas where surface ozone is sensitive to BVOC emissions are different in autumn and in summer, which is primarily due to the change of prevailing wind over the PRD; nevertheless, in both autumn and summer, the surface ozone is most sensitive to the BVOC emissions in the urban area because the area is usually VOC-limited. Three additional experiments concerning the sensitivity of surface ozone to MEGAN input variables were also performed to assess the sensitivity of surface ozone to MEGAN drivers, and the results reveal that land cover and
\end{abstract}

emission factors of BVOCs are the most important drivers and have large impacts on the predicted surface ozone.

\section{Introduction}

Formed by photochemical reactions involving volatile organic compounds (VOCs) and the oxides of nitrogen $\left(\mathrm{NO}_{\mathrm{x}}=\mathrm{NO}+\mathrm{NO}_{2}\right)($ Chameides et al., 1992), surface ozone is the most abundant atmospheric photochemical oxidant and can adversely affect vegetation as well as human health and welfare (Aneja et al., 1992). VOCs can originate either from anthropogenic or biogenic sources. Globally speaking, biogenic VOC (BVOC) emissions are much higher than anthropogenic VOC emissions, accounting for $\sim 90 \%$ of the total atmospheric VOC emissions (Guenther et al., 1995). Measurement and modeling of BVOC emissions are essential for understanding regional and global atmospheric chemistry, carbon cycle, and climate change.

Over the past few decades, research has been conducted to measure emissions of carbon-containing compounds from vegetation, and hundreds of BVOCs have been identified. At the present time, most studies of BVOCs focus on four aspects: (1) understanding the mechanisms controlling BVOC emissions; (2) improving and applying BVOC measurement technology; (3) developing and improving BVOC emission models and estimating the emissions; and (4) quantifying the atmospheric chemistry impacts of BVOC emissions 
(Guenther et al., 1995, 1996a, b, 1999, 2006, 2012; Carslaw et al., 2000; Wang et al., 2011). Most BVOCs quickly react with $\mathrm{OH}$ and then influence atmospheric composition, especially ozone and secondary organic aerosol (Carslaw et al., 2000; Carlton et al., 2009), by a series of chemical reactions. The impacts of BVOC emissions on global chemistry have been investigated using global models (Granier et al., 2000; Poisson et al., 2000; Collins et al., 2002; Sanderson et al., 2003; Laothawornkitkul et al., 2009), and the results show that BVOC emissions can affect global chemistry significantly. High-resolution studies on regional and local scales also show that the impacts of BVOC emissions on air quality are very important (Thunis and Cuvelier, 2000; Solmon et al., 2004; Li et al., 2007; Curci et al., 2009; Bao, et al., 2009; Marley et al., 2009; Geng et al., 2011; Fu and Liao, 2012; Wei et al., 2007). It has also been shown that accurate BVOC emission estimates are needed for developing effective pollution-control strategies (Pierce et al., 1998).

Located in the central Guangdong province in southern China, the Pearl River delta (PRD) region is one of the most developed areas in China. Nine major cities in this region form a supercity cluster, including Guangzhou (GZ), Dongguan (DG), Foshan (FS), Shenzhen (SZ), Zhuhai (ZH), Zhongshan (ZS), Jiangmen (JM), Huizhou (HZ), and Zhaoqing (ZQ). Because of its geographic location, the PRD region is influenced by a subtropical monsoon climate, having the characteristics associated with high temperature in most seasons. Vegetation in this region is mainly subtropical evergreen forest and some of the species, such as eucalyptus, have very high BVOC emission capacities (Winters et al., 2009). These features enhance BVOC emissions in the PRD region. Emission inventory studies have suggested that the BVOC emissions in the PRD are high, and that the annual average isoprene emission flux is higher than in Beijing, China, and the average value for North America (Zheng et al., 2010a; Wang et al., 2011).

Because of the remarkable economic development and rapid urban expansion, air quality in the PRD has been deteriorating in recent years. Ozone and particle matter are the major air pollutants in this region, with the maximum hourly average ozone concentration exceeding $180 \mathrm{ppb}$ in 2008 (the national standard is $\sim 100 \mathrm{ppb}$ in China). Society and government are concerned about this issue, and a series of studies have been carried out to provide an in-depth understanding and a comprehensive record, including (1) concentration measurement and analysis (Zhang et al., 2008; Zheng et al., 2010b), (2) the relationship between ozone and its precursors (Cheng et al., 2010; Wang et al., 2010), (3) the meteorological analysis of a particular season with high ozone concentration (Fan et al., 2008) and (4) the impacts of anthropogenic emissions on ozone formation (Wang et al., 2005; Li, 2011). Recently, some studies showed that BVOC emissions could affect surface ozone in the PRD region. Tang et al. (2007) investigated VOCs at urban, suburban, and rural sites in the PRD region, and found that biogenic isoprene contributed significantly to the ozone formation potential, especially at the remote site. However, that study only focused on the concentration and ozone formation potential of VOCs, and did not quantify how BVOC emissions affect surface ozone spatiotemporally. Wei et al. (2007) employed an atmospheric chemical model to study the impacts of BVOC emissions on an ozone episode during a tropical storm in the PRD region, and the results indicated that BVOC emissions could increase the surface ozone peak up to $15.2 \mathrm{ppb}$. However, that study only focused on a specific short period. Overall, the impact of BVOC emissions on surface ozone formation in PRD is still not well understood and needs to be addressed.

The objectives of this paper are to (1) evaluate biogenic emission model performance at a typical subtropical forest site in the PRD region and (2) investigate the impacts of BVOC emissions on surface ozone in this region preliminarily. In this study, we used the Model of Emissions of Gases and Aerosols from Nature (MEGAN) version 2.1 to estimate BVOC emissions with local high resolution landcover data and BVOC emission factor data, and applied the MEGAN output in a fully coupled weather-chemistry model (the Weather Research and Forecasting model coupled with Chemistry: WRF-Chem) to study the impacts of seasonal and regional variability in BVOC emissions on surface ozone. The paper is organized as follows. In Sects. 2 and 3 , the modeling framework and evaluation data, respectively, are described. The model performance, by comparison to observations - including those of meteorology, BVOC emissions and surface ozone - and the results of the sensitivity experiments are presented in Sect. 4. The conclusions are presented in Sect. 5.

\section{WRF-Chem/MEGAN modeling framework}

\subsection{WRF-Chem model}

The model used in this study is the chemistry version of the WRF model (WRF-Chem v3.2.1). The WRF model is a mesoscale non-hydrostatic meteorological model that includes several options for physical parameterizations of the planetary boundary layer (PBL), cloud processes and land surface (Skamarock et al., 2008). The chemistry version is a version of WRF coupled with an "online" chemistry model, in which meteorological and chemical components of the model are predicted simultaneously (Grell et al., 2005; Fast et al., 2006). Emission, chemical formation and removal, transport and deposition are considered when WRF-Chem predicts the chemical components.

Three domains (d01, d02, and d03) were adopted in this study, and the spatial resolutions of these three domains were 27,9 and $3 \mathrm{~km}$, respectively (Fig. 1) with 24 vertical layers up to $100 \mathrm{hPa}$. To reduce the biases in modeled meteorology, analysis nudging was used in d01 (Deng et al., 2007). The National Centers for Environmental Prediction (NCEP) 


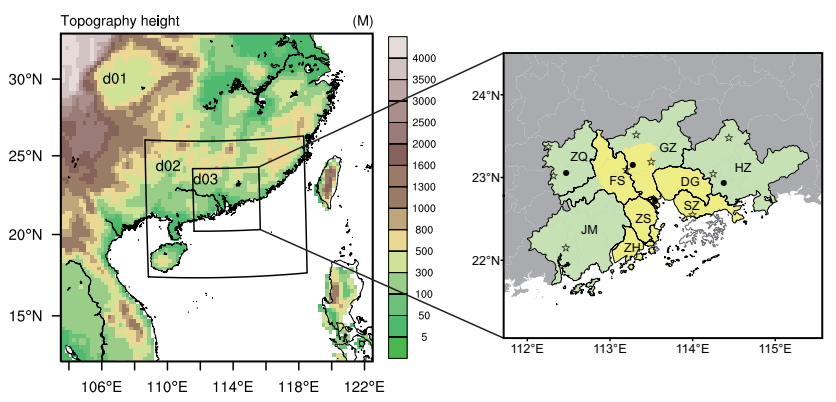

Fig. 1. Modeling domains, topography, location of meteorological monitoring sites (star) and air quality monitoring sites (filled circle). Definition of the three regions: grey area is the outside PRD; green area is the rural PRD; yellow area is the central PRD.

$1^{\circ} \times 1^{\circ}$ final analysis data were used as initial and boundary conditions for meteorology. Main options for physical and chemical schemes utilized in this study are listed in Table 1 (Chen and Dudhia, 2001; Martilli et al., 2002; Janjic et al., 2002; Kain and Fritsch, 1990, 1993; Lin et al., 1983; Chou et al., 1998; Mlawer et al., 1997). The Kain-Fritsch cumulus parameterization scheme was used in the $\mathrm{d} 01$ and $\mathrm{d} 02$, and no cumulus parameterization scheme was used for the finest domain (d03) because the convection is assumed to be reasonably well characterized by the explicit microphysics (Wang et al., 2007).

The gas phase chemistry scheme CBM-Z (Zaveri and Peters, 1999) was selected for this study because it can better represent surface ozone that agrees with the observations in the PRD region (Wang et al., 2009). CBM-Z is a new lumped structure photochemical mechanism for large-scale applications. It extends the original Carbon Bond Mechanism IV (CBM-IV) framework to function properly at larger spatial scales and longer timescales. It includes 132 photolytic gas phase reactions, 7 of which are isoprene chemical reactions, and 52 chemical species.

It should be noted that monoterpenes are not treated as a unique species in the CBM-Z chemical scheme. Instead, we accounted for terpene species (e.g. $\alpha$-pinene and $\beta$-pinene) by lumping them into the OLEI (internal olefin carbons) and OLET (terminal olefin carbon) categories for this study. The reaction rate constant with OH for OLEI (OLET) in WRF-Chem has been compared with the measured values for some individual monoterpene species (e.g., $\alpha$-pinene, $\beta$ pinene and limonene). The comparison indicates that the reaction rate constant with OH for OLEI is very close to the measured value ( $\alpha$-pinene), while the reaction rate constant with $\mathrm{OH}$ for OLET is lower than the measured values for the monoterpenes lumped into this category (e.g., $\beta$-pinene and limonene) (Atkinson and Arey, 2003). OLET includes not only the biogenic alkenes, but also the anthropogenic alkenes (which are emitted in greater magnitude than biogenic alkenes). Moreover, the contribution of terpenes to ozone formation is lower than that of isoprene, even when

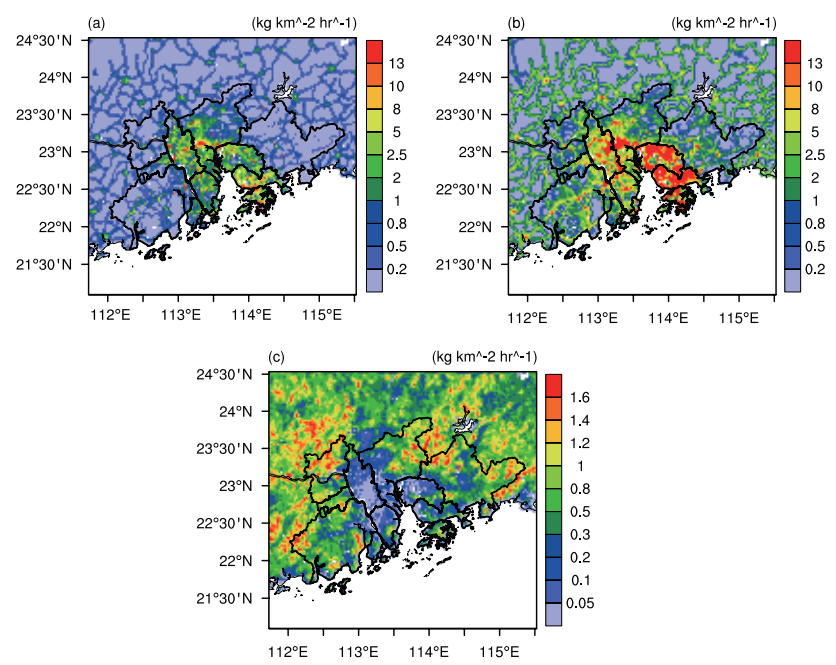

Fig. 2. Spatial distributions of anthropogenic and biogenic emission flux in the Pearl River delta (PRD) region: (a) nitric oxide; (b) total anthropogenic VOCs; (c) total biogenic VOCs.

terpene chemistry is treated individually (Curci et al., 2009). As a result, the use of the model default reaction rate constant with OH for OLEI and OLET for monoterpenes should be a reasonable approach to finding the relative contribution of monoterpene emissions to the surface ozone over the PRD region in this study.

A highly resolved spatial PRD regional emission inventory for the year 2006 was developed with the use of the best available domestic emission factors and activity data (Zheng et al., 2009). The regional emission inventory was updated to 2010 using the statistical emission data mainly from government inspection reports (Liu et al., 2013). Figure 2a-b shows the spatial distributions of nitric oxide and anthropogenic VOC emissions, which agree well with observed vehicle and industrial emissions. Biogenic VOC emissions are described in the following subsection.

\subsection{BVOC emissions from MEGAN}

MEGAN is a model used to represent emissions of gases and aerosols from nature; it has been widely used to estimate global and regional BVOC emissions (Guenther et al., 2006, 2012; Sakulyanontvittaya et al., 2008). The recently developed MEGAN v2.1 was used to estimate BVOC emissions in this study. MEGAN v2.1 can estimate emissions of up to 146 BVOC species - including isoprene, monoterpene, sesquiterpene and other compounds (e.g. acids, aldehyde, alcohols and some other volatile compounds) - and output them as individual compounds or as the inputs required for specific atmospheric chemistry mechanisms (Guenther et al., 2012).

Meteorology, leaf area index (LAI), plant functional types (PFTs) and emission factors (EFs) are the inputs required to drive MEGAN. In this study, the meteorology data from WRF-Chem, the MODIS LAI data, the local high-resolution 
Table 1. WRF-Chem configuration.

\begin{tabular}{ll}
\hline Process & WRF-Chem option \\
\hline Microphysics & Lin \\
Long-wave radiation & RRTM \\
Short-wave radiation & Goddard \\
Surface layer & Monin-Obukhov (Janjic) scheme \\
Land surface model & Noah LSM \\
Urban canopy model & Multi-layer, Building Environment Parameterization \\
& (BEP) scheme \\
Boundary layer scheme & Mellor-Yamada-Janjic TKE scheme \\
Cumulus parameterization & Kain-Fritsch (new Eta) parameterization scheme \\
Photolysis scheme & Fast-J \\
Gas-phase mechanism & CBM-Z \\
\hline
\end{tabular}

PFT data (Wang et al., 2011) and observed emission factors of BVOCs for local plant species (Bai and Wang, 2001a, b; Klinger et al., 2002; Tsui et al., 2009) were included to constrain the MEGAN BVOC emissions model. The local highresolution PFT data have been verified with field surveys and tree statistics data from Guangdong Forestry Bureau (Wang et al., 2011).

The total estimated emission of BVOCs over $\mathrm{d} 03$ is $67.3 \times 10^{6} \mathrm{~kg}$ in November 2010, and isoprene emission accounts for $\sim 60 \%$ of total BVOC emissions (Table 2). Figure $2 \mathrm{c}$ shows the averaged total BVOC emission flux in $\mathrm{d} 03$, which indicates that there are considerable spatial variations in the total BVOC emissions over $\mathrm{d} 03$ and that $\mathrm{d} 03$ can be divided into three regions: the outside PRD, the rural PRD and the central PRD (Fig. 1). The outside PRD is the area inside the modeling domain but outside the PRD region. The rural PRD represents the rural and less developed areas in the PRD region, including Huizhou, north and northeast of Guangzhou, and west of Foshan, Jiangmen and Zhaoqing. Excluding the rural PRD, the remaining PRD region is defined as the central PRD in this study and can be described as the urban area in the PRD. The amounts of BVOC emissions from the three regions contribute to $75.9 \%, 19.8 \%$ and $4.2 \%$ of the total BVOC emissions from the whole domain, respectively (Table 2 ).

\subsection{Simulation setups}

To thoroughly evaluate the impacts of BVOC emissions on surface ozone over the PRD region, annual ensemble simulations are preferred. However, annual ensemble simulations with this fully coupled atmosphere-chemistry model demand a huge amount of computing time. The alternative approach - used for this study - is to select the highest ozone month as the simulated period in order to minimize computer resource requirements and investigate the effects under high ozone concentration, which is typically of greatest interest for the air quality regulatory community.
Multiple years of observation show that high ozone concentrations frequently occurred in autumn in the PRD (Zheng et al., 2010b) because of the high frequency of a surface highpressure system and the descent motion outside of hurricane and sea breeze in this season (Fan et al., 2008). A field experiment was conducted at Dinghushan using the Relaxed Eddy Accumulation (REA) technique to quantify BVOC emission flux from a typical natural forest in the PRD region in fall 2010. So, November 2010 was chosen for the simulated period to investigate the role of BVOC emissions during a period of high ozone in this study.

Details of simulation setup are listed in Table 3. A onemonth long simulation using anthropogenic emissions and total BVOC emissions was conducted as the control run for this study. Excluding anthropogenic emissions, case 1 was designed to estimate the impacts of BVOC emissions on surface ozone in a clean atmosphere, which could indicate the background value of surface ozone due to BVOC emissions in this region. In case 2 , the $\mathrm{BVOC}$ emissions were removed in order to quantify the impacts of BVOC emissions on surface ozone in the real atmospheric environment. As isoprene is emitted into the troposphere in greater quantities than other non-methane BVOC emissions, and as it is very reactive in the atmosphere, case 3 was designed to estimate the impacts of isoprene emissions on surface ozone. Case 4 and case 5 were designed to study the regional impacts by excluding the BVOC emissions from the outside PRD and the rural PRD regions, respectively, and the impacts from the central PRD were defined as the difference of the impacts from the whole domain and the impacts from the outside and the rural PRD. Case 6 was a seasonal comparison simulation to estimate the impacts of BVOC emissions in the PRD during summer.

\section{Evaluation data}

Measurements of whole forest canopy BVOC emission flux and ambient measurements of isoprene concentrations in Dinghushan $\left(112.53^{\circ} \mathrm{E}, 23.17^{\circ} \mathrm{N}\right)$ were used to evaluate 
Table 2. Amount of BVOC emissions $\left(10^{3}\right.$ ton $)$ during the simulated period.

\begin{tabular}{lrrrr}
\hline \multirow{2}{*}{ Species } & \multicolumn{4}{c}{ Emission amount } \\
\cline { 2 - 5 } & Whole domain & Central PRD & Rural PRD & Outside PRD \\
\hline Isoprene & 42.7 & 1.6 & 8.8 & 32.3 \\
Terpene & 19.0 & 0.9 & 3.5 & 14.7 \\
Other BVOCs & 5.5 & 0.3 & 1.1 & 4.1 \\
Total BVOCs & 67.3 & 2.8 & 13.3 & 51.1 \\
\hline
\end{tabular}

Table 3. Description of model simulations.

\begin{tabular}{lll}
\hline Simulation & Anthropogenic emissions & Biogenic VOC emissions \\
\hline Control & All anthropogenic emissions & All BVOCs \\
Case 1 & No anthropogenic emissions & All BVOCs \\
Case 2 & All anthropogenic emissions & No BVOCs \\
Case 3 & All anthropogenic emissions & No isoprene \\
Case 4 & All anthropogenic emissions & No BVOCs in outside PRD \\
Case 5 & All anthropogenic emissions & No BVOCs in rural PRD \\
Case 6 & with (without) anthropogenic emissions & All BVOCs in 1-9 July \\
\hline
\end{tabular}

the MEGAN performance in this study. This measured site is in the northwest of PRD, which is $86 \mathrm{~km}$ away from Guangzhou, and is mainly covered by subtropical evergreen mixed forest. Most trees at this location are more than 100 years old (Zhou et al., 2007).

\subsection{REA measurements}

The measurement of whole forest canopy BVOC emission flux was made on a $37 \mathrm{~m}$ high flux tower operated by the South China Botanical Garden of the Chinese Academy of Sciences in Dinghushan. The REA system was installed at a height of $31 \mathrm{~m}$ above ground and more than $10 \mathrm{~m}$ above the forest canopy (canopy height is around $17 \mathrm{~m}$ ).

The REA technique has been explained elsewhere (Businger and Oncley, 1990; Bowling et al., 1998). In short, two air samples are collected over a statistically meaningful time period $(\sim 30 \mathrm{~min})$ : one consisting of updrafts and the other consisting of downdrafts. While alternating sampling between the up and down reservoirs depending on the vertical wind direction, the flow occurs at a constant flow rate. The duration of sample collection for each reservoir is related to the frequency at which the wind eddies change vertical wind direction (Baker et al., 2001). The flux calculation can be described as follows:

$F=\beta \sigma_{\mathrm{w}}\left(C_{\mathrm{u}}-C_{\mathrm{d}}\right)$,

where $\beta$ is a dimensionless coefficient which is determined empirically from fast response temperature measurements, $\sigma_{\mathrm{w}}$ is the standard deviation of the vertical wind over the collection period, and $C_{\mathrm{u}}$ and $C_{\mathrm{d}}$ are measured concentrations collected in the updraft and downdraft reservoirs.
For this study, all samples were collected on Tenax TA and Carbograph 5TD solid adsorbent cartridges around midday (12:00-14:00 LT) on three days in October $(17,18,31)$, one day in November (20) and three days in December (4, 10 and 21) during 2010. At the Dinghu site, all seven days had fairweather conditions with no rain. The duration for each sample was $30 \mathrm{~min}$ and total sampling period was $90 \mathrm{~min}$, providing three contiguous samples for each sample day. Samples were shipped to the lab at NCAR (National Center for Atmospheric Reach, Boulder, CO, USA) for chemical analysis by Gas Chromatography. Cartridges were desorbed using an Ultra auto sampler with a Unity thermal desorption system (MARKES International, Llantrisant, UK) coupled to a 7890A series Gas Chromatograph with a 5975C Electron Impact Mass Spectrometer and flame ionization detector (GC-MS/FID, Agilent Technologies, Santa Clara, CA, USA). VOCs were separated with an Agilent HP-5ms column (Agilent Technologies, USA) using an initial oven temperature of $35^{\circ} \mathrm{C}$ for $1 \mathrm{~min}$, followed by a temperature ramp of $6^{\circ} \mathrm{C} \mathrm{min}-1$ to $80^{\circ} \mathrm{C}$, then $3^{\circ} \mathrm{C} \mathrm{min}^{-1}$ to $155^{\circ} \mathrm{C}$, then $10^{\circ} \mathrm{C} \mathrm{min}{ }^{-1}$ to $190^{\circ} \mathrm{C}$, and finally $25^{\circ} \mathrm{C} \mathrm{min}^{-1}$ to $260^{\circ} \mathrm{C}$, with a $5 \mathrm{~min}$ final hold. Helium was used as a carrier gas, at a flow rate of $3 \mathrm{~mL} \mathrm{~min}^{-1}$. Concentrations were quantified using FID calibrated with a National Institute of Standards and Technology (NIST) traceable standard. Compounds with co-eluting peaks were quantified with the MS using specific masses that were normalized by the same or similar mass in the internal standards (tetramethylethene and dihydronapthalene) that were introduced for each run using a $1 \mathrm{~mL}$ loop. Identifications were mostly based on comparison of retention times and mass spectra of authentic standards, but in a 
few cases were based on the retention times and mass spectra in the Adams (2001) and NIST databases.

\subsection{Ambient measurements}

Ambient air samples were collected at Dinghushan in November 2008 using 2 L electropolished stainless steel canisters. During field sampling, an Entech restrictive sampler (Part No. 39-RS-3, Entech Instruments Inc., CA, USA) was adopted to allow each canister to be filled in approximately $60 \mathrm{~min}$. All the samples were analyzed at the Guangzhou Institute of Geochemistry (GIG), Chinese Academy of Sciences. Detailed sampling and chemical analysis for samples are reported by Zhang et al. (2013).

Measurements by Bai et al. (2001a) of the ambient isoprene concentrations at Dinghushan in summer (June to August) of 1995 were also used to evaluate the MEGAN performance. Details about the sampling and chemical analysis methods have been described by Bai et al. (1998, 2001a). The air samples were collected in $0.8 \mathrm{~L}$ electropolished stainless steel canister every 2 weeks from June to August 1996, and all air samples were sent to the Massachusetts Institute of Technology for chemical analysis by a HP-5890A Gas Chromatograph.

\section{Result and discussion}

\subsection{Model performance}

\subsubsection{Meteorology}

Available daily averaged data observed at 9 weather stations for November 2010 were used to validate the simulated $2 \mathrm{~m}$ temperature, $10 \mathrm{~m}$ wind speed, and $2 \mathrm{~m}$ relative humidity from the control run. The simulated downward shortwave radiation was validated by the hourly downward solar radiation observed at Dinghu site. The statistics of the verification - including the bias, mean absolute errors (MAE) and root mean square errors (RMSE) - are listed in Table 4.

The result shows that the simulated downward shortwave radiation is higher than the observed downward shortwave radiation. This may at least partly be due to the fact that the model did not include aerosol feedback in this study. Because of the simulated higher downward shortwave radiation, modeled $2 \mathrm{~m}$ temperature has a warm bias of $1.2^{\circ} \mathrm{C}$, and $2 \mathrm{~m}$ relative humidity has a dry bias of $-2.1 \%$. The simulated $10 \mathrm{~m}$ wind speed is $2.2 \mathrm{~m} \mathrm{~s}^{-1}$ higher than the observed value, which is expected since WRF generally overestimates wind speed in a flat area (Roux et al., 2009; Mass and Ovens, 2010, 2011).

\subsubsection{BVOC emissions}

The analysis of REA samples shows that the main BVOCs emitted from the Dinghushan forest include isoprene, $\alpha$ - pinene, $\beta$-pinene, camphene and D-limonene. After excluding fluxes that did not meet required conditions, isoprene emission fluxes range between 0.002 and $0.215 \mathrm{mg} \mathrm{m}^{-2} \mathrm{~h}^{-1}$ and monoterpene emission fluxes range between 0.063 and $0.313 \mathrm{mg} \mathrm{m}^{-2} \mathrm{~h}^{-1}$ at midday in autumn 2010 .

The land-cover inputs used to parameterize the Dinghu site in MEGAN include a PFT composition of $42.3 \%$ broadleaf trees and $20.9 \%$ needleleaf trees. Monitored meteorological data at the Dinghu site were used to drive MEGAN. Model results show that the isoprene emission fluxes vary from 0.366 to $3.577 \mathrm{mg} \mathrm{m}^{-2} \mathrm{~h}^{-1}$, and that monoterpene emission fluxes are between 0.149 and $0.617 \mathrm{mg} \mathrm{m}^{-2} \mathrm{~h}^{-1}$ at midday during the REA sampling period.

This initial study of above canopy fluxes in the PRD region indicates that isoprene emissions can be very different from the model estimate. However, there are very high uncertainties in modeled isoprene estimates for almost all vegetation types (Zheng et al., 2010a), so additional ambient observed data were used to further evaluate the MEGAN performance on isoprene. Considering the chemical loss and simple vertical mixing, a simple box model was used to relate the modeled isoprene emission flux to a mixed layer concentration. Details about this simple box model have been described by Guenther et al. (1996b), and the equation can be written as:

$C=\frac{E}{Z_{\mathrm{i}} \times L}$,

where $C$ is the mean scalar mixing ratio; $E$ is the emission flux; $Z_{\mathrm{i}}(\mathrm{m})$ is the height of mixed-layer capping inversion; and $L\left(\mathrm{~s}^{-1}\right)$ the oxidation rate of isoprene. Only $\mathrm{OH}$ and ozone are considered to oxidize isoprene in this study. So $L$ is defined as $\left[K_{\mathrm{OH}} C_{\mathrm{OH}}\right]+\left[K_{\text {ozone }} C_{\text {ozone }}\right]$, where $K_{\mathrm{OH}}$ and $K_{\text {ozone }}$ are reaction rate constants, and $\mathrm{C}_{\mathrm{OH}}$ and $C_{\text {ozone }}$ are mixing ratios of hydroxyl radical and ozone, respectively.

We used the $\mathrm{OH}$ and ozone reaction rate coefficients reported by Atkinson and Arey (2003) and the observed ozone mixing ratios at Dinghu site to estimate the chemical loss. No measured $\mathrm{OH}$ concentration data are available at this site, so the maximum $\mathrm{OH}$ concentration $\left(26 \times 10^{6}\right.$ molecules $\left.\mathrm{cm}^{-3}\right)$ in the PRD on a summer day (Lu et al., 2012) was applied in this calculation.

The result shows that isoprene concentrations based on MEGAN emission fluxes range between 0.1 to $1.3 \mathrm{ppb}$ for midday average in autumn, which tends to be considerably higher than the measurement $(\sim 0.1 \mathrm{ppb})$ at the Dinghu site. By contrast, the modeled midday isoprene concentration at the Dinghu site in summer is $2.2 \mathrm{ppb}$, which agrees with the measured isoprene concentration in summer at this site (Bai et al., 2001a).

In conclusion, the evaluation indicates that monoterpene emission fluxes estimated by MEGAN agree reasonably well with the observations at the Dinghu site; isoprene is considerably overestimated in autumn but reasonably agrees with the observed values for summer. The evaluation of MEGAN isoprene estimates indicates that our knowledge of its seasonal 
Table 4. Verification statistics of meteorological simulations.

\begin{tabular}{|c|c|c|c|c|c|c|}
\hline \multirow{2}{*}{ Meteorological variable } & \multirow{2}{*}{ No } & \multicolumn{2}{|c|}{ MEAN } & \multirow{2}{*}{ Bias } & \multirow{2}{*}{ MAE } & \multirow{2}{*}{ RMSE } \\
\hline & & Obs & Sim & & & \\
\hline SWDOWN $\left(\mathrm{W} \mathrm{m}^{-2}\right)$ & 1 & 163.8 & 229.8 & 64.2 & 82.9 & 152.0 \\
\hline $2 \mathrm{~m}$ TEMP $\left({ }^{\circ} \mathrm{C}\right)$ & 9 & 19.5 & 20.7 & 1.2 & 1.4 & 1.6 \\
\hline $10 \mathrm{~m}$ WSPD $\left(\mathrm{m} \mathrm{s}^{-1}\right)$ & 9 & 1.8 & 3.9 & 2.2 & 2.2 & 2.4 \\
\hline $2 \mathrm{~m} \mathrm{RH}(\%)$ & 9 & 66.3 & 64.2 & -2.1 & 8.5 & 8.5 \\
\hline
\end{tabular}

SWDOWN: downward shortwave radiation; $2 \mathrm{~m}$ TEMP: temperature at $2 \mathrm{~m}$; Obs: observation; Sim: simulation; MAE: mean absolute error; RMSE: root mean square error; No: number of stations.
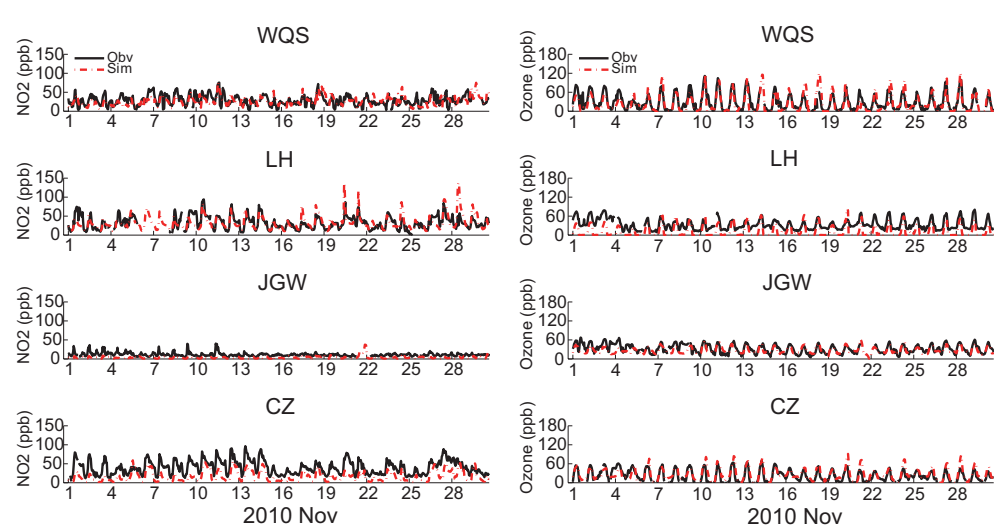

Fig. 3. The simulated and observed hourly nitrogen dioxide $\left(\mathrm{NO}_{2}\right)$ and surface ozone at 4 PRD monitoring sites in November 2010 (the location of the sites are shown in Fig. 1).

variation is limited. Possible reasons for the overestimated autumn (dry season) isoprene emission flux by MEGAN include:

1. It was the dry season and the observed soil moisture was low during the REA sampling period. Some studies indicate that drought can influence the isoprene emission (Pegoraro et al., 2004), and the MEGAN emission algorithms may not account for seasonal variations in isoprene emissions very well at sites including significant wet and dry seasons (Barkley et al., 2009).

2. The temperature was low and kept decreasing during the REA sampling period. Cool temperature can lead to a downregulation of isoprene emission (Petron et al., 2001), and the MEGAN algorithms may not adequately account for the influence of periods beyond the past 10 days (Grote et al., 2010).

3. The REA technique may have underestimated the isoprene flux. Comparisons between REA and direct eddy flux measurements have demonstrated that the REA technique can accurately measure trace gas fluxes when REA system is working properly (Bowling et al., 1999). Moreover, Bowling et al. (1999) also note that mixing of the up and down samples will decrease the measured concentration difference, which would lead to an underestimated isoprene flux. A mechanical failure of the REA system could have resulted in mixing of the samples.

We cannot determine which of these is most likely because we do not have enough observations to provide a more rigorous evaluation of MEGAN in the PRD region. More field experiments are needed to accurately quantify the BVOC emission flux in the PRD, which will provide a more in-depth understanding of the BVOC emissions in this region and further improve the MEGAN model. Considering the uncertainties of BVOC emissions estimated by MEGAN, sensitivities of surface ozone to BVOC emission model driving variables were assessed in this study and the results are presented in Sect. 4.6.

\subsubsection{Surface ozone}

Available hourly observations at 4 monitoring sites (including Wanqinsha (WQS), Luhu (LH), Jinguowan (JGW) and Chengzhong (CZ)) for November were used to validate the ozone simulation from the control run. The locations of these 4 monitoring sites are shown in Fig. 1. The WQS site is located $30-50 \mathrm{~km}$ downwind of the central GuangzhouDongguan-Foshan metropolitan urban area, and represents a regional scale site. The LH site is in central Guangzhou, 


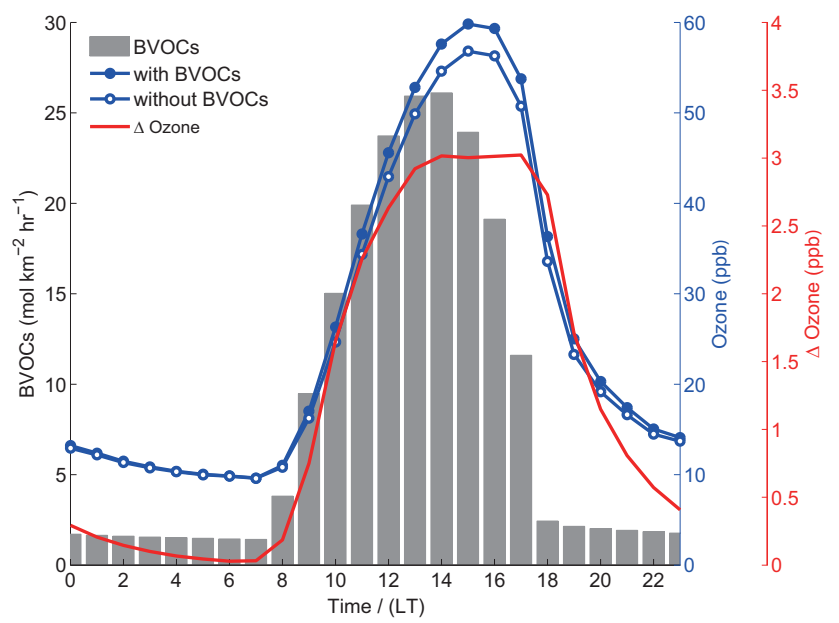

Fig. 4. Diurnal variation of the total BVOC emission rate and surface ozone concentration with and without BVOC emissions, and the difference in their ozone over the PRD region.

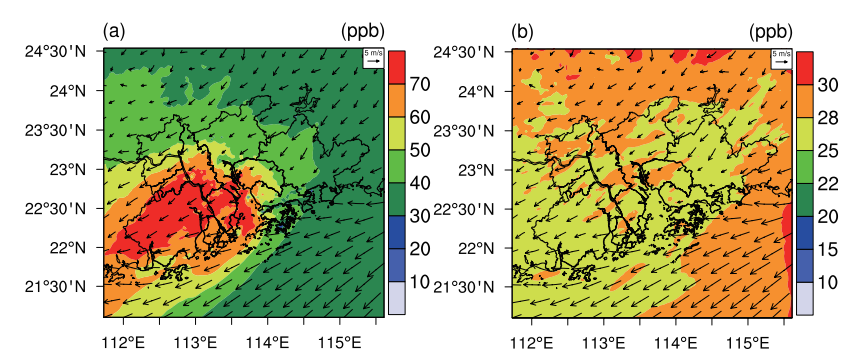

Fig. 5. Spatial distributions of surface ozone at 15:00 LT in (a) control run and (b) in background run.

which is a typical urban site. The JGW site is in Huizhou, which was chosen as a rural or less developed area site in eastern PRD. The CZ site in Zhaoqing is representative of rural or less developed areas in western PRD. The four sites represent the main areas in PRD and will be used to illustrate the impacts of BVOC on surface ozone in the different areas of PRD.

Figure 3 shows that the control run reproduced the diurnal variations and magnitude of ozone reasonably well at most sites. As an important precursor of ozone, the comparison of $\mathrm{NO}_{2}$ at the monitoring sites further demonstrates that the ozone formation is captured reasonably well over the domain throughout the period. The model appeared to underestimate ozone at LH, especially at night. This might be related to a combination of several factors, such as the uncertainties in the precursor emissions, meteorological parameters, and chemical mechanisms (Wang et al., 2010). Considering the prevailing northerly winds in November, the underestimation of ozone at LH might be caused mainly by the uncertainties in emissions in northern rural areas of Guangzhou and distant northern areas outside of Guangzhou. The overestimation of surface wind speeds might result in more transport and less
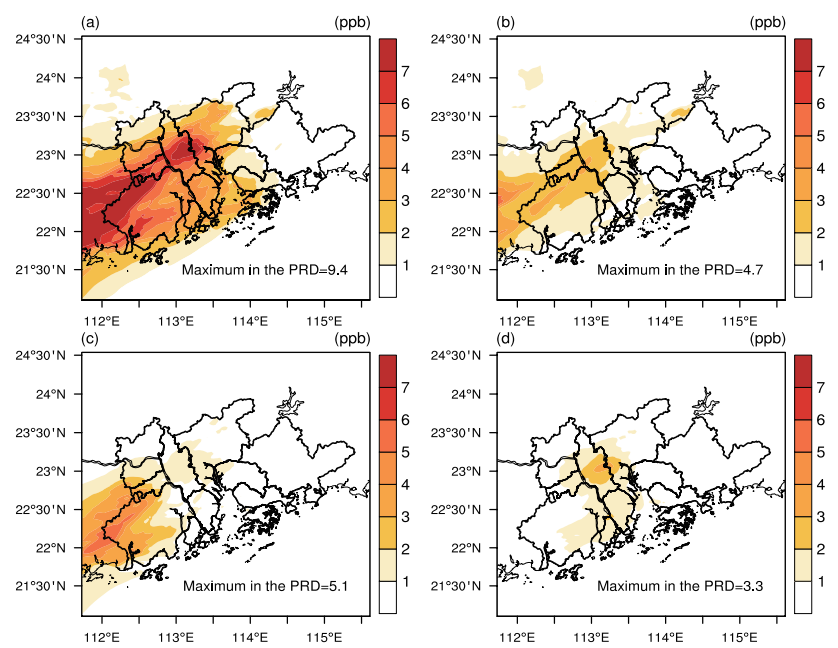

Fig. 6. Changes of the surface ozone peak due to BVOC emissions: (a) spatial distribution of surface ozone changes due to BVOC emissions from the whole domain; (b) spatial distribution of surface ozone changes due to BVOC emissions from the outside PRD; (c) spatial distribution of surface ozone changes due to BVOC emissions from the rural PRD; (d) spatial distribution of surface ozone changes due to BVOC emissions from the central PRD.

accumulation of ozone and its precursors, and this is probably another important contributor to the underestimation of ozone at LH. Moreover, the nighttime vertical diffusion is not easily simulated by current mesoscale meteorological models (Wang et al., 2010).

Surface ozone concentration increases significantly and has a large spatiotemporal variation over PRD. The surface ozone peak occurs at 15:00 LT, with a regional averaged value of $\sim 50 \mathrm{ppb}$ (Fig. 4), and the ozone concentration is higher in western PRD and the south of central PRD, because of the northeast prevailing wind (Fig. 5a).

\subsection{Impacts of BVOC emissions on surface ozone}

There is a distinct difference in surface ozone concentration between simulations with and without BVOC emissions over the PRD region (Fig. 4). This indicates that BVOC emissions generate additional surface ozone and contribute $\sim 3.0 \mathrm{ppb}$ the surface ozone peak over the PRD region on average. As the most abundant non-methane BVOC, isoprene contribution to the impacts of the total BVOC emissions on the surface ozone peak in PRD is $\sim 57 \%$. The impact is most significant in the downwind area and in the urban area, where the impact is on average $9.4 \mathrm{ppb}$ and $7.9 \mathrm{ppb}$, respectively (Fig. 6a). This result also reveals that the impact of BVOC emissions on the surface ozone peak can be as high as 24.8 ppb over the PRD in November 2010 (Fig. 7a).

Figure 8 shows the impacts of BVOC emissions on surface ozone at 4 air quality monitoring sites. The BVOC emissions at the JGW site are the highest, but the impacts on surface 


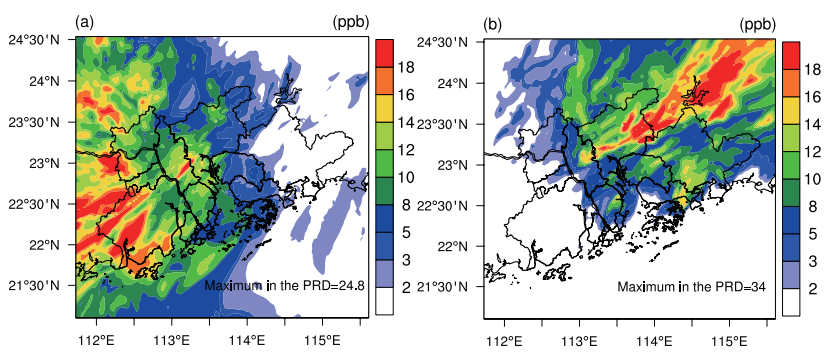

Fig. 7. Maximum hourly impacts of BVOC emissions on the surface ozone peak (a) in autumn and (b) in summer.

ozone peak at the JGW site are the least significant (less than $2 \mathrm{ppb}$ ). This is mainly because (1) low $\mathrm{NO}_{\mathrm{x}}$ does not favor ozone formation because it is $\mathrm{NO}_{\mathrm{x}}$-limited at the JGW site (Zhang et al., 2008; Wang et al., 2010); and (2) the upwind location is not impacted by ozone accumulation. As a monitoring site located in the urban area, the BVOC emissions at the LH site are 10 times lower than those at the JGW site, but the contribution of BVOC emissions to surface ozone is the highest, more than $4 \mathrm{ppb}$. The impacts at $\mathrm{CZ}$ reach a small peak at around 11:00 LT, which accounts for the photochemical influence; the increment continues to increase, reaching a maximum at 18:00 LT, which can be partially attributed to the influence of ozone transport, because $\mathrm{CZ}$ is on the downwind edge of PRD in November. This comparison also indicates that BVOC emissions have a higher impact on the surface ozone peak in the urban area than in the rural or less developed areas in the PRD region.

Depending on the daily variations of wind speed and wind direction, 3 distinct impact conditions are classified: north wind condition, calm wind condition and south wind condition (Fig. 9). The occurrence probabilities of the three conditions are $60.0 \%, 36.7 \%$, and $3.3 \%$, respectively. South wind condition is a rare condition because the PRD region is controlled by a high ridge that is located to the east of the PRD. During south wind condition, BVOC emissions affect the surface ozone peak more in the rural or less developed areas, causing an average $2.8 \mathrm{ppb}$ increment to the surface ozone peak over the PRD. North wind condition, the most common condition during the simulation, results in a regional increment of $1.1 \mathrm{ppb}$ to the surface ozone peak, and the surface ozone increases more in the urban and downwind areas. Calm wind is conducive to ozone accumulation and it is easy to cause high ozone concentrations that can lead to an ozone pollution episode. During calm wind condition, BVOC emissions affect the surface ozone peak in the urban and downwind areas most, causing an average $2.1 \mathrm{ppb}$ increment over the PRD region.

\subsection{Regional variability}

In this section, the impacts of BVOC emissions from the outside, central and rural PRD regions are estimated. The results indicate that the BVOC emissions from the outside PRD affect the surface ozone in the urban area and part of the downwind area, and the BVOC emissions from the central PRD mainly affect the urban area, while the BVOC emissions from the rural PRD affect the west edge of the downwind area more significantly (Fig. 6).

The impacts of BVOC emissions on surface ozone are different in various PRD cities (Fig. 10). This can be explained by (1) the amount of BVOC emission; (2) the relative location of emission sources; and (3) the meteorological conditions, including horizontal transport and vertical diffusion. Surface ozone is most sensitive to BVOC emissions in Foshan and Jiangmen, followed by Zhaoqing, Zhongshan, Guangzhou, Zhuhai, Dongguan, Shenzhen and Huizhou. The ozone in Foshan is more sensitive to the BVOC emissions from outside PRD and central PRD, with increments of 2.0 and $2.3 \mathrm{ppb}$ respectively. The ozone in Jiangmen is more sensitive to the BVOC emissions from outside PRD and rural $\mathrm{PRD}$, which have highest increments of 2.0 and $2.5 \mathrm{ppb}$, respectively.

There are two peaks in the diurnal variation of the surface ozone increment in Zhaoqing; the smaller one appears at midday while the larger one appears in the late afternoon. Similar to the peaks at the CZ site, the peak that appears in the late afternoon in Zhaoqing is mainly related to transport. The diurnal variations of surface ozone increment in Guangzhou and Dongguan are similar to those in Zhaoqing.

\subsection{Seasonal variability}

Under the influence of the East Asian Monsoon, the PRD region has southerly or southwesterly prevailing wind directions during the summer. A comparison experiment to investigate the impacts of seasonal variability in BVOC emissions on ozone formation was conducted for 1-9 July (referred to here as the summer case). In summer case, BVOCs and isoprene emissions are 3.2 and 3.6 times higher than those in November (referred to here as the autumn case).

Results indicate that the high values of ozone concentration are in the northern and the eastern PRD (Fig. 11a). Similar to the situation in autumn, BVOC emissions significantly affect the surface ozone peak in the downwind areas in summer, but the locations change to include the northeast of Guangzhou, Dongguan, Shenzhen and Huizhou (Fig. 11b). Results also reveal that the impact on surface ozone peak $(9.8 \mathrm{ppb})$ is higher than that over the PRD region in autumn, with the maxima over the PRD region as high as $34.0 \mathrm{ppb}$ (Fig. 7b).

Figure 12 shows a comparison of the impacts of BVOC emissions on surface ozone in PRD cities in different seasons. The comparison reveals that the ranking of BVOC sensitive areas changes in summer due to the change of prevailing wind. The surface ozone in Guangzhou becomes the most sensitive to BVOC emissions, followed by Huizhou, Dongguan, Foshan, Shenzhen, Zhenshan, Zhaoqing, Zhuhai, 

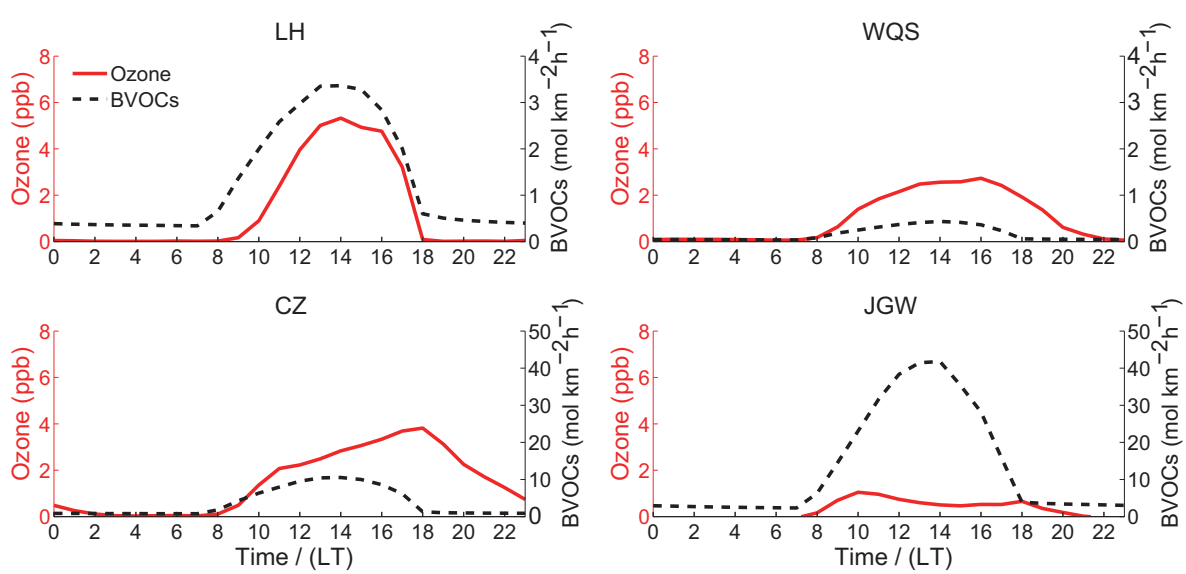

Fig. 8. Diurnal variations of modeled surface ozone changes and the BVOC emission rate at 4 monitoring sites. The red dashed line shows surface ozone changes (ppb) while the black solid line shows the BVOC emission rate $\left(\mathrm{mol} \mathrm{km}^{-2} \mathrm{~h}^{-1}\right)$.

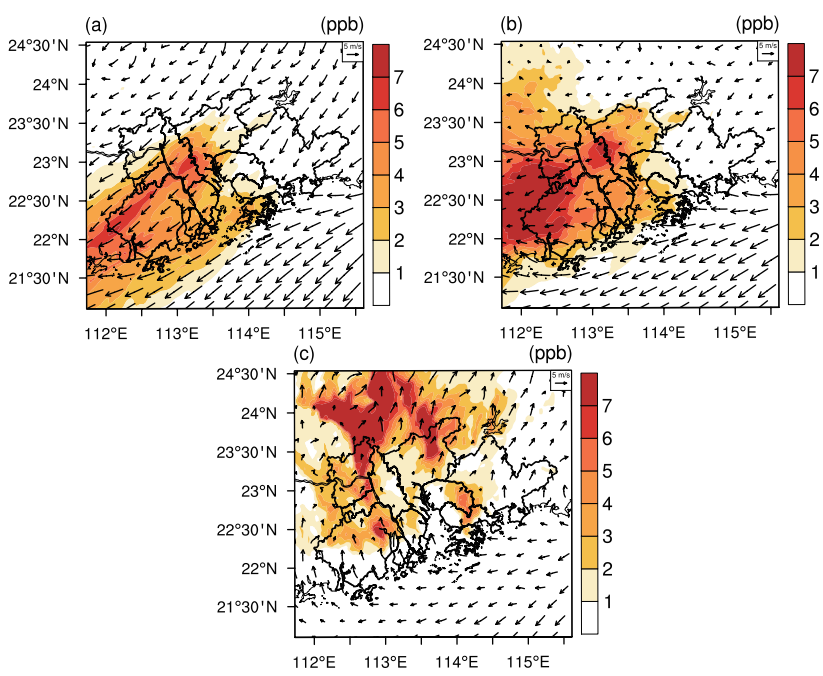

Fig. 9. Spatial distributions of the surface ozone peak changes due to BVOC emissions under different meteorological conditions: (a) north wind condition; (b) calm wind condition; (c) south wind condition.

and Jiangmen. The highest surface ozone increment in Guangzhou is $8.8 \mathrm{ppb}$, which is $5.6 \mathrm{ppb}$ higher than in autumn. Guangzhou is the capital of Guangdong province as well as the economic, transportation, and cultural center in the PRD, which makes it a key target for ozone reduction strategies.

There is a significant difference in the diurnal variation of the surface ozone increment in Zhaoqing between summer and autumn. Two peaks are also shown in the diurnal variation of the surface ozone increment in summer in Zhaoqing, but the larger one shifts to occur at midday, while in autumn it occurs in late afternoon. The transport influence in Zhaoqing is weaker in summer, because Zhaoqing is in the upwind area. So the shift indicates that not only the trans-
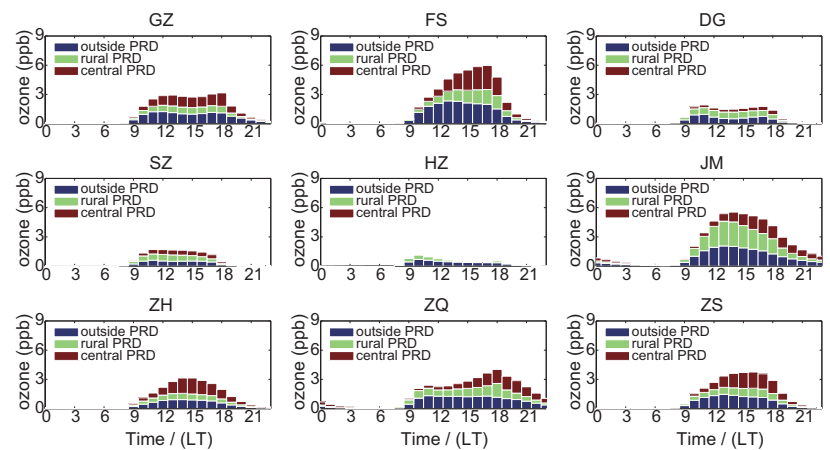

Fig. 10. Diurnal variation of the surface ozone increment in PRD cities due to BVOC emissions from different regions.

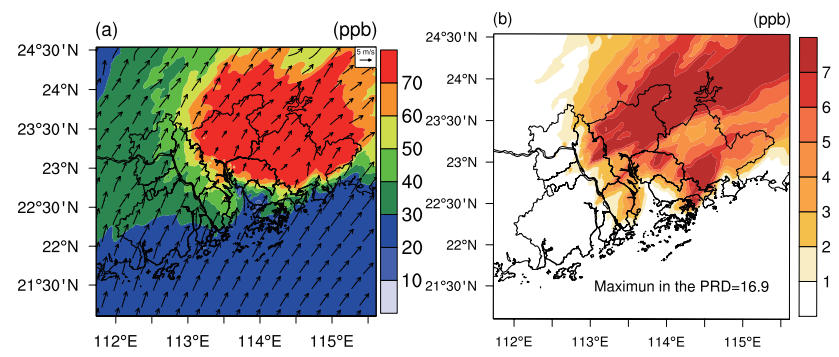

Fig. 11. Spatial distributions of (a) surface ozone and (b) the impacts of BVOC emissions on surface ozone at 15:00 LT in summer.

port but also other factors, such as PBL compression, cause the peak in late afternoon in autumn in Zhaoqing. There is a peak in the surface ozone increment in the diurnal variations in Guangzhou and in Huizhou in summer, which is related to the influence of transport and the accumulation caused by the decreasing PBL height. 


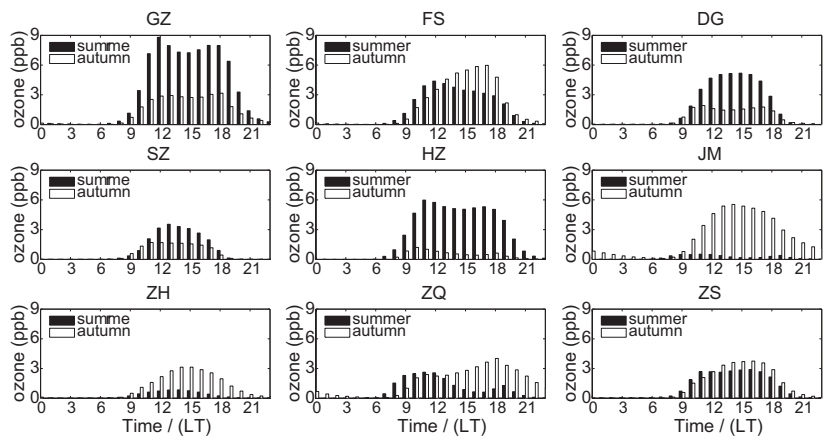

Fig. 12. Comparison of BVOC impacts on surface ozone in PRD cities in summer and in autumn.

\subsection{Background influence of BVOC emissions on surface ozone}

As natural products, BVOC emissions are considered to be responsible for the background level of surface ozone. By excluding all anthropogenic emissions, the background level of surface ozone due to BVOC emissions over the PRD region was estimated. The results indicate that the daily average ozone concentration is $\sim 25 \mathrm{ppb}$, and that there is a small temporal variability of surface ozone in the background, varying from 22 to $29 \mathrm{ppb}$ in daytime, with the maximum (28.2 ppb) occurring at 15:00 LT. The spatial distribution of surface ozone at 15:00 LT showed in Fig. 5b indicates that the spatial distribution is relatively smooth over the PRD region.

BVOC emissions alone do not result in an ozone problem. However, the higher the background level is, the more difficult it is to solve the ozone problem. Thus, BVOC emissions must be considered when examining anthropogenicemission-control strategies in the PRD, especially since the local government now is taking measures to reduce the anthropogenic emissions of ozone precursors from industry and mobile sources, which will increase the importance of BVOC emissions in the future.

\subsection{Sensitivity of surface ozone to BVOC emissions model driving variables}

Land cover, emission factors, and meteorological parameters are important drivers of MEGAN, and the uncertainties of estimated BVOC emissions and their impacts on surface ozone are hence associated with uncertainties in these inputs (Wang et al., 2011; Fu and Liao, 2012). In this part of the study, 3 experiments were performed to assess the sensitivity of surface ozone to the MEGAN drivers.

\subsubsection{Land cover}

Eucalyptus is an important BVOC emitter, because it has high terpenoid (including isoprene, monoterpene and sesquiterpene) emissions. Moreover, eucalyptus is the dominant tree in the Guangdong province and is widely planted in the PRD region because of its high economic value. We conducted a land-cover-change sensitivity study by changing all forest to eucalyptus, except for protected areas in national and local natural parks. The eucalyptus BVOC emission factors were adopted, including an isoprene emission factor of $24000 \mu \mathrm{g} \mathrm{m}^{-2} \mathrm{~h}^{-1}, \sim 2$ times higher of that used in the control run.

The results show that changing forests to eucalyptus increases the total BVOC emissions over the PRD by $\sim 230 \%$ and isoprene emissions by $\sim 315 \%$. The impact on the surface ozone peak is $8.4 \mathrm{ppb}$ on average over the PRD region, which is $5.4 \mathrm{ppb}$ higher than in the control run.

The sensitivity of surface ozone at 4 monitoring sites was examined. The result shows that the surface ozone peak at the $\mathrm{CZ}$ site has the highest response to the BVOC emissions increase, followed by the LH, JGW and WQS sites. The change in relative ranking is mainly due to the increase of BVOC emissions and the change in spatial distribution of BVOC emissions.

\subsubsection{Emission factor}

BVOC emission factors dominate the total uncertainties in BVOC emission estimates and have been estimated to range from a factor of 3 to a factor of 5 (Lamb et al., 1987; Simpson et al., 1999; Stewart et al., 2003). However, these uncertainty estimates are for landscapes where emission measurements have characterized many of the dominant species. We consider the impact of a factor of 3 uncertainty in emission factors. We also consider a higher level of uncertainty, a factor of 15 , which we feel better represents the uncertainties associated with emission factors estimated for PRD landscapes where there are relatively few emission measurements.

We consider uncertainty of a factor of 3 as well as a higher level of uncertainty (of a factor of 15) to represent uncertainties associated with the PRD landscape where there are relatively few emission measurements.

The results show that the impacts of BVOC emissions on surface ozone peak over the PRD region increase (decrease) with increasing (decreasing) the BVOC emissions. Biogenic VOC emissions contribute $\sim 7.3$ (1.1) to the surface ozone peak if the emission factors of BVOCs are increased (decreased) by a factor of 3 , and the impacts of BVOC emissions on surface ozone peak vary between 15.5 and $0.2 \mathrm{ppb}$ if the emission factors of BVOCs are changed by a factor of 15 .

\subsubsection{Meteorology}

Solar radiation and temperature are the most important meteorological parameters for BVOC emissions. Hence, we perturbed temperature and daytime solar radiation by their RMSE (Table 4) for each time step of the MEGAN calculations for temperature, and only in daytime for solar 
radiation.

SWDOWN $=\operatorname{control}_{(\text {swdown) }} \pm \mathrm{RMSE}_{(\text {swdown) }}$

$\mathrm{TEMP}=\operatorname{control}_{(\mathrm{TEMP})} \pm \mathrm{RMSE}_{(\mathrm{TEMP})}$

As expected, increasing (decreasing) solar radiation and temperature produces more (less) BVOC emissions. BVOC emissions varied between -11.9 and $29.9 \%$ due to solar radiation perturbation, and led to $3.5 \mathrm{ppb}(2.6 \mathrm{ppb})$ impacts on the surface ozone peak.

Similarly, there is a $35.2 \%$ increment ( $10.6 \%$ decrement) of BVOC emissions due to the temperature increasing (decreasing), resulting in a $3.6 \mathrm{ppb}(2.5 \mathrm{ppb})$ impact on surface ozone peak.

\section{Conclusions}

This study indicates that BVOC emissions can significantly affect surface ozone in the PRD region, and that the impacts are complex.

There is an average $\sim 3 \mathrm{ppb}$ surface ozone peak associated with BVOC emissions, with a maximum impact of $24.8 \mathrm{ppb}$ in autumn, and there is an average $\sim 10 \mathrm{ppb}$ surface ozone peak increase due to the BVOC emissions, with the maximum increment of $34.0 \mathrm{ppb}$ in summer over the PRD region. As the most abundant non-methane BVOC species, isoprene contributes $\sim 57 \%$ of the total impact of BVOC emissions on surface ozone peak.

The impact on surface ozone is most significant in the downwind area and the urban area, but it is likely that the impact of BVOC emissions on the patterns of surface ozone peak varies with seasons because the patterns of BVOC emissions and prevailing wind are different throughout the year. In autumn, Foshan and Jiangmen are most affected by the BVOC emissions, while in summer, Guangzhou and Huizhou are the most sensitive. .

Sensitivity experiments show that surface ozone responds differently to various MEGAN drivers. Land cover is an important MEGAN driver, playing a major role in determining the amount and spatial distribution of BVOC emissions. Emission factors are another important MEGAN factor to which surface ozone is very sensitive. Under the current BVOC emissions spatial distribution, ozone in the urban area is more sensitive to BVOC emission changes.

The few measurements of BVOC emissions in the PRD region provide only a broad constraint on model simulations of BVOC emissions in this region. The high diversity of BVOC emission data sources and the incomplete understanding of the processes controlling the seasonal variations prevent a more thorough assessment of the temporal and spatial variability simulated by models. A much larger data set that covers both seasonal and regional distributions is required to get a more in-depth understanding of BVOC emissions, rigorously evaluate the ability of a model to accurately predict BVOC emissions, and further develop the emission model in this region. Further work will also quantitatively investigate the chemical and physical processes that control the impact of BVOC emissions on surface ozone in the PRD region.

Acknowledgements. This research was supported by the Natural Science Foundation of China projects U0833001, 41275018 and 41275100, and the key program of the Natural Science Foundation of Guangdong Province under Grant no S2012020011044. The National Center for Atmospheric Research is sponsored by the US National Science Foundation. The authors thank G. Zhou and the South China Institute of Botany for allowing us to work at their research site in Dinghushan as well as the invaluable assistance they provided for this study. We also thank J. Zheng of South China University of Technology for providing PRD emission inventory. S. Situ also gratefully acknowledges the NCAR Advanced Study Program (ASP).

Edited by: K. Schaefer

\section{References}

Adams, R. P.: Identification of essential oil components by gas chromatography/mass spectrometry quadrupole, Allured Publ. Corp.: Carol Stream, 2001.

Aneja, V., Yoder, G. T., and Arya, S. P.: Ozone in the urban southeastern United States, Environ. Pollut., 75, 39-44, 1992.

Atkinson, R. and Arey, J.: Atmospheric degradation of Volatile Organic Compounds, Chem. Rev., 103, 4605-4638, 2003.

Bai, J. H. and Wang, X. M.: A Study of Nonmethane Hydrocarbons at Subtropical Forest Part I: Seasonal Variation (Flask Sampling), China Climatic and Environmental Research, 6, 286-293, 2001a (in Chinese).

Bai, J. H. and Wang, X. M.: A Study of Nonmethane Hydrocarbons at Subtropical Forest Part II: Diurnal variation, China Climatic and Environmental Research, 6, 456-466, 2001b (in Chinese).

Bai, J. H., Wang, M. X, Graham, J., Prinn, R. G., and Huang, Z. L.: Primary Study on the Concentrations of Nonmethane Hydrocarbon emitted from the Forest, Chinese Journal of Atmospheric Sciences, 12, 247-251, 1998 (in Chinese).

Baker, B., Guenther, A., and Greenberg, J.: Canopy level fluxes of 2-methyl-3buten-2-ol, acetone, and methanol by a portable relaxed eddy accumulation system, Environ. Sci. Technol., 35, 1707-1708, 2001.

Bao, H., Shrestha, K. L., Kondo, A., Kaga, A., and Inoue, Y.: Modeling the influence of biogenic volatile organic compound emissions on ozone concentration during summer season in the Kinki region of Japan, Atmos. Environ., 44, 421-431, 2009.

Barkley, M. P., Palmer, P. I., Smedt, I. D., Karl, T., Guenther, A., and Roozendael, M. V.: Regulated large-scale annual shutdown of Amazonian isoprene emissions?, Geophys. Res. Lett., 36, L04803, doi:10.1029/2008GL036843, 2009.

Bowling, D. R., Turnipseed, A. A., Delany, A. C., Baldocchi, D. D., Greenberg, J. P., and Monson, R. K.: The use of relaxed eddy accumulation to measure biosphere-atmosphere exchange of isoprene and other biological trace gased, Oecologia, 116, 306-315, 1998.

Bowling, D. R., Delany, A. C., Turnipseed, A. A., Baldocchi, D. D., and Monson, R. K.: Modification of the relaxed eddy 
accumulation technique to maximize measured scalar mixing ratio differences in updrafts and downdrafts, J. Geophys. Res., 104, 9121-9133, 1999.

Businger, J. A. and Oncley, S. P.: Flux Measurement with Conditional Sampling, Notes and Correspondence, 7, 349-352, 1990.

Carlton, A. G., Wiedinmyer, C., and Kroll, J. H.: A review of Secondary Organic Aerosol (SOA) formation from isoprene, Atmos. Chem. Phys., 9, 4987-5005, doi:10.5194/acp-9-4987-2009, 2009.

Carslaw, N., Bell, N., Lewis, A. C., McQuaid, J. B., and Pilling, M. J.: A detailed case study of isoprene chemistry during the EASE96 Mace Head campaign, Atmos. Environ., 34, 28272836, 2000.

Chameides, W. L., Fehsenfeld, F., Rodgers, M. O., Cardelino, C., Martinez, J., Parrish, D., Lonneman, W., Lawson, D. R., Rasmussen, R. A., Zimmerman, P., and Greenberg, J.: Ozone precursor relationships in the abmbient atmosphere, J. Geophys. Res., 97, 6037-6055, 1992.

Chen, F. and Dudhia, J.: Coupling an advanced land surfacehydrology model with the Penn State-NCAR MM5 modeling system. Part I: Model implementation and sensitivity, Mon. Weather Rev. 129, 569-585, 2001.

Cheng, H. R., Guo, H., Wang, X. M., Saunders, S. M., Lam, S. H. M., Jiang, F., Wang, T. J., Ding, A. J., Lee, S. C., and Ho, K. F.: On the relationship between ozone and its precursors in the Pearl River Delta: application of an observation-based model (OBM), Environ. Sci. Pollut. R., 17, 547-560, doi:10.1007/s11356-0090247-9, 2010.

Chou, M. D., Suarez, M. J., Ho, C. H., Yan, M. H. H., and Lee, K. T.: Parameterizations for cloud overlapping and shortwave singlescattering properties for use in general circulation and cloud ensemble models, J. Climate, 11, 202-214, 1998.

Collins, W. J., Derwent, R. G., Johnson, C. E., and Stevenson, D. S.: The oxidation of organic compounds in the troposphere and their global warming potentials, Clim. Change, 52, 453-479, 2002.

Curci, G., Beekmann, M., Vautard, R., Smiatek, G., Steinbrecher, R., Theloke, J., and Friedrich, R.: Modelling study of the impact of isoprene and terpene biogenic emissions on European ozone levels, Atmos. Environ., 43, 1444-1455, 2009.

Deng, A. J., Stauffer, D. R., Dudhia, J., Otte, T., and Hunter, G. K.: Update analysis nudging FDDA in WRF-ARW, The 8th WRF Users'sWorkshop, 11-15 June, Boulder, CO, available at: http://www.mmm.ucar.edu/wrf/users/workshops/ WS2007/abstracts/4-8Deng.pdf (29 November 2013), 2007.

Fan, S. J., Wang, B. M., Tesche, M., Engelmann, R., Althausen, A., Liu, J., Zhu, W., Fan, Q., Li, M. H., Ta, N., Song, L. L., and Leong, K.: Meteorological conditions and structures of atmospheric boundary layer in October 2004 over Pearl River Delta area, Atmos. Environ., 42, 6174-6186, 2008.

Fast, J. D., Gustafson Jr., Easter, W. I., Zaveri, R. C., Barnard, J. C., Chapman, E. G., Grell, G. A., and Packham, S. E.: Evolution of ozone, particulates and aerosol direct radiative forcing in the vicinity of Houston using a fully coupled meteorology-chemistry-aerosol model, J. Geophys. Res., 111, D21305, doi:10.1029/2005JD006721, 2006.

$\mathrm{Fu}$, Y. and Liao, H.: Simulation of the interannual variations of biogenic emissions of volatile organic compounds in China: Impacts on tropospheric ozone and secondary organic aerosol, Atmos. Environ., 59, 170-185, 2012.
Geng, F., Tie, X., Guenther, A., Li, G., Cao, J., and Harley, P.: Effect of isoprene emissions from major forests on ozone formation in the city of Shanghai, China, Atmos. Chem. Phys., 11, 1044910459, doi:10.5194/acp-11-10449-2011, 2011.

Granier, C., Petron, G., Muller, J. F., and Brasseur, G.: The impact of natural and anthropogenic hydrocarbons on the tropospheric budget of carbon monoxide, Atmos. Environ, 34, 5255-5270, 2000.

Grell, G. A., Peckham, S. E., Schmitz, R., McKeen, S. A., Frost, G., Skamarock, W. C., and Eder, B.: Fully coupled "online" chemistry within the WRF model, Atmos. Environ., 39, 6957-6975, 2005.

Grote, R., Keenan, T., Lavoir, A.-V., and Staudt, M.: Process-based simulation of seasonality and drought stress in monoterpene emission models, Biogeosciences, 7, 257-274, doi:10.5194/bg7-257-2010, 2010.

Guenther, A., Hewitt, C. N., Erickson, D., Fall, R., Geron, C., Graedel, T., Harley, P., Klinger, L., Lerdau, M., McKay, W. A., Pierce, T., Scholes B., Steinbrecher, R., Tallamraju, R., Taylor, J. and Aimmerman, P.: A global model of natural volatile organic compound emissions, J. Geophys. Res., 100, 8873-8892, 1995.

Guenther, A., Baugh, W., Davis, K., Hampton, G., Harley, P., Klinger, L., Vierling, L., and Zimmerman P.: Isoprene fluxes measured by enclosure, relaxed eddy accumulation, surface layer gradient, mixed layer gradient, and mixed layer mass balance techniques, J. Geophys. Res., 101, 18555-18567, 1996a.

Guenther, A., Zimmerman, P., Klinger, L., Greenberg, J., Ennis, C., Davis, K., and Pollock, W.: Estimates of regional natural volatile organic compound fluxes from enclosure and ambient measurements, J. Geophys. Res., 101, 1345-1359, 1996b.

Guenther, A., Baugh, B., Brasseur, G., Greenberg, J., Harley, P., Klinger, L., Serca, D., and Vierling, L.: Isoprene emission estimates and uncertainties for the central african espresso study domain, J. Geophys. Res., 104, 30625-30639, 1999.

Guenther, A., Karl, T., Harley, P., Wiedinmyer, C., Palmer, P. I., and Geron, C.: Estimates of global terrestrial isoprene emissions using MEGAN (Model of Emissions of Gases and Aerosols from Nature), Atmos. Chem. Phys., 6, 3181-3210, doi:10.5194/acp-63181-2006, 2006.

Guenther, A. B., Jiang, X., Heald, C. L., Sakulyanontvittaya, T., Duhl, T., Emmons, L. K., and Wang, X.: The Model of Emissions of Gases and Aerosols from Nature version 2.1 (MEGAN2.1): an extended and updated framework for modeling biogenic emissions, Geosci. Model Dev., 5, 1471-1492, doi:10.5194/gmd-51471-2012, 2012.

Janjic, Z. L.: Nonsingular Implementation of the Mellor-Yamada Level 2.5 Scheme in the NCEP Meso model, NCEP Office Note, 437, 61, 2002.

Kain, J. S. and Fritsch, J. M.: A one-dimensional entraining/detraining plume model and its application in convective parameterization, J. Atmos. Sci., 47, 2784-2802, 1990.

Kain, J. S. and Fritsch, J. M.: Convective parameterization for mesoscale model: The Kain-Fritsch scheme. The Representation of Cumulus Convection in Numerical Model, Meteor. Mon., 24, 165-170, 1993.

Klinger, L. F., Li, Q. J., Guenther, A., Greenberg, J., Baker, B., and Bai, J. H.: Assessment of volatile organic compound emissions from ecosystems of China, J. Geophys. Res. 107, ACH 16-19, 2002. 
Lamb, B., Guenther, A., Gay, D., and Westberg, H.: A national inventory of biogenic hydrocarbon emissions. Atmos. Environ., 21, 1695-1705, 1987.

Laothawornkitkul, J., Taylor, J. E., Paul, N. D., and Hewitt, C. N.: Biogenic volatile organic compounds in the Earth system, New Phytol., 183, 27-51, 2009.

Li, G. H., Zhang, R. Y., Fan, J. W., and Tie, X. X.: Impacts of biogenic emissions on photochemical ozone production in Houston, Texas, J. Geophys. Res., 112, D10309, doi:10.1029/2006JD007924, 2007.

Li, Y.: Numerical Studies on Ozone Source Apportionment and Formation Regime and their Implications on Control Strategies, $\mathrm{Ph} . \mathrm{D}$. thesis, Hong Kong University of Science and Technology, Hongkong, 2011.

Lin, Y. L., Farley, R. D., and Orvilie, H. D.: Bulk parameterization of the snow field in a cloud model, J. Clim. Appl. Meteorol., 22, 1065-1092, 1983.

Liu, H., Wang, X. M., Zhang, J. P., He, K. B., Wu, Y., and Xu, J. P.: Emission controls and changes in air quality in Guangzhou during the Asian Games, Atmos. Environ., 76, 81-93, 2013.

Lu, K. D., Rohrer, F., Holland, F., Fuchs, H., Bohn, B., Brauers, T., Chang, C. C., Häseler, R., Hu, M., Kita, K., Kondo, Y., Li, X., Lou, S. R., Nehr, S., Shao, M., Zeng, L. M., Wahner, A., Zhang, Y. H., and Hofzumahaus, A.: Observation and modelling of $\mathrm{OH}$ and $\mathrm{HO}_{2}$ concentrations in the Pearl River Delta 2006: a missing $\mathrm{OH}$ source in a VOC rich atmosphere, Atmos. Chem. Phys., 12, 1541-1569, doi:10.5194/acp-12-1541-2012, 2012.

Marley, N. A., Gaffney, J. S., Tackett, M., Sturchio, N. C., Heraty, L., Martinez, N., Hardy, K. D., Marchany-Rivera, A., Guilderson, T., MacMillan, A., and Steelman, K.: The impact of biogenic carbon sources on aerosol absorption in Mexico City, Atmos. Chem. Phys., 9, 1537-1549, doi:10.5194/acp-9-1537-2009, 2009.

Martilli, A., Clappier, A., and Rotach, M. W.: An urban surface exchange parameterization for mesoscale models, Bound.-Lay. Meteorol., 104, 261-304, 2002.

Mass, C. and Ovens, D.: WRF model physics: Problems, solutions and a new paradigm for progress. Preprints, WRF Users' Workshop, Boulder, CO, NCAR, 2010.

Mass, C. and Ovens, D.: Fixing WRF's high speed wind bias: a new subgrid scale drag parameterization and the role of detailed verification, Preprints, 24th Conf. on Weather and Forecasting/20th Conf. on Numerical Weather Prediction, Seattle, WA, Amer. Meteor. Soc., 9B.6, available at: https://ams.confex. com/ams/91Annual/webprogram/Paper180011.html, 2011.

Mlawer, E. J., Taubman, S. J., Brown, P. D., Iacono, M. J., and Clough, S. A.: Radiative transfer for inhomogeneous atmosphere: RRTM, a validated correlated-K model for longwave, J. Geophys. Res., 102, 16663-16682, 1997.

Pegoraro, E., Rey, A., Greenberg, J., Harley, P., Grace, J., Malhi, Y., and Guenther, A: Effect of drought on isoprene emission rates from leaves of Quercus virginiana Mill, Atmos. Environ., 38, 6149-6156, 2004.

Petron, G., Harley, P., Greenberg, J., and Guenther, A.: Seasonal temperature variations influence isoprene emission, Geophys. Res. Lett., 28, 1707-1710, 2001.

Pierce, T., Geron, C., Bender, L., Dennis, R., Tonnesen, G., and Guenther, A.: Influence of increased isoprene emissions on regional ozone modeling, J. Geophys. Res.-Atmos., 103, 2561125629, 1998.
Poisson, N., Kanakidou, M., and Crutzen, P. J.: Impact of nonmethane hydrocarbons on tropospheric chemistry and the oxidizing power of the global troposphere: 3-dimensional modeling results, J. Atmos. Chem., 36, 157-230, 2000.

Roux, G., Liu, Y., Monache, L. D., Sheu, R.-S., and Warner, T. T.: Verification of high resolution WRF-RTFDDA surface forecasts over mountains and plains. Preprints, WRF Users' Workshop, Boulder, CO, NCAR, 2009.

Sakulyanontvittaya, T., Duhl, T., Wiedinmyer, C., Helmig, D., Matsunaga, S., Potosnak, M., Milford, J., and Guenther, A.: Monoterpene and sesquiterpene emission estimates for the United States, Environ. Sci. Technol., 42, 1623-1629, 2008.

Sanderson, M. G., Jones, C. D., Collins, W. J., Johnson, C. E., and Derwent, R. G.: Effect of climate change on isoprene emissions and surface ozone levels, Geophys. Res. Lett., 30, 1936, doi:10.1029/2003GL017642, 2003.

Simpson, D., Winiwarter, W., Börjesson, G., Cinderby, S., Ferreiro, A., Guenther, A., Hewitt, C. N., Janson, R., Khalil, M. A. K., Owen, S., Pierce, T. E., Puxbaum, H., Shearer, M., Skiba, U., Steinbrecher, R., Tarrason, L., and Öquist, M. G.: Inventorying emissions from nature in Europe, J. Geophys. Res., 104, 81138152, 1999.

Skamarock, W. C., Klemp, J. B., Dudhia, J., Gill, D. O., Barker, D. M., Duda, M. G., Huang, X. Y., Wang, W., and Powers, J. G.: A Description of the Advanced Research WRF Version 3, Technical Report, National Center for Atmospheric Research, TN475,+STR, 2008.

Solmon, F., Sarrat, C., Serca, D., Tulet, P., and Rosset, R.: Isoprene and monoterpenes biogenic emissions in France: modeling and impact during a regional pollution episode, Atmos. Environ., 38, 3853-3865, 2004.

Stewart, H. E., Hewitt, C. N., Bunce, R. G. H., Steinbrecher, R., Smiatek, G., and Schoenemeyer, T.: A highly spatially and temporally resolved inventory for biogenic isoprene and monoterpene emissions - model description and application to Great Britain, J. Geophys. Res., 108, 4644, doi:10.1029/2002JD002694, 2003.

Tang, J. H., Chan, L. Y., Chan, C. Y., Li, Y. S., Chang, C. C., Liu, S. C., Wu, D., and Li, Y. D.: Characteristics and diurnal variations of NMHCs at urban, suburban, and rural sites in the Pearl River Delta and a remote site in South China, Atmos. Environ., 41, 8620-8632, 2007.

Thunis, P. and Cuvelier, C.: impact of biogenic emissions on ozone formation in the Mediterranean area - a BEMA modeling study, Atmos. Environ., 34, 467-481, 2000.

Tsui, J., Guenther, A., Yip, W. K., and Chen, F.: A biogenic volatile organic compound emission inventory for Hong Kong, Atmos. Environ, 43, 6442-6448, doi:doi:10.1016/j.atmosenv.2008.01.027, 2009.

Wang, X., Zhang, Y., Hu, Y., Zhou, W., Lu, K., Zhong, L., Zeng, L., Shao, M., Hu, M., and Russell, A. G.: Process analysis and sensitivity study of regional ozone formation over the Pearl River Delta, China, during the PRIDE-PRD2004 campaign using the Community Multiscale Air Quality modeling system, Atmos. Chem. Phys., 10, 4423-4437, doi:10.5194/acp-10-4423-2010, 2010.

Wang, X. M., Carmichael, G., Chen, D. L., Tang, Y. H., and Wang, T. J.: Impacts on different emission sources on air quality during 
March 2001 in the Pearl River Delta (PRD) region, Atmos. Environ., 39, 5227-5241, 2005.

Wang, X. M., Lin, W. S., Yang, L. M., Deng, R. R, and Lin, H.: A numerical study of influences of urban land-use change on ozone distribution over the Pearl River Delta Region, China, Tellus B, 59, 633-641, 2007.

Wang, X. M., Chen, F., Wu, Z. Y., Zhang, M. G., Tewari, M., Guenther, A., and Wiedinmyer, C.: Impacts of Weather Conditions Modified by Urban Expansion on Surface Ozone: Comparison between the Pearl River Delta and Yangtze River Delta Regions, Adv. Atmos. Sci., 26, 962-972, 2009.

Wang, X. M., Situ, S. P., Guenther, A., Chen, F., Wu, Z. Y., Xia, B. C., and Wang, T. J.: Spatiotemporal variability of biogenic terpenoid emissions in Pearl River Delta, China, with highresolution land-cover and meteorological data, Tellus B, 63, 241254, 2011.

Wei, X. L., Li, Y. S., Lam, K. S., Wang, A. Y., and Wang, T. J.: Impact of biogenic VOC emissions on a tropical cyclone-related ozone episode in the Pearl River Delta region, China, Atmos. Environ., 41, 7851-7861, 2007.

Winters, A. J., Adams, M. A., Bleby, T. M., Rennenberg, H., Steigner, D., Steinbrecher, R., and Kreuzwieser, J.: Emissions of isoprene, monoterpene and short-chained carbonyl compounds from Eucalyptus spp. in southern Australia, Atmos. Environ., 43, 3035-3043, 2009.

Zaveri, R. Z. and Peters, L. K.: A new lumped structure photochemical mechanism for long-scale applications, J. Geophys. Res., 104, 30387-30414, 1999.
Zhang, Y. H., Su, H., Zhong, L. J., Cheng, Y. F., Zeng, L. M., Wang, X. S., Xiang, Y. R., Wang, J. L., Gao, D. F., Shao, M., and Liu, S. C.: Regional ozone pollution and observation-based approach for analyzing ozone-precursor relationship during the PRIDEPRD2004 campaign, Atmos. Environ., 42, 6203-6218, 2008.

Zhang, Y. L., Wang, X. M., Barletta, B., Simpson, I. J., Blake, D. R., Fu, X. X., Zhang, Z., He, Q. F., Liu, T. Y., Zhao, X. Y., and Ding, $X$. : Source attributions of hazardous aromatic hydrocarbons in urban, suburban and rural areas in the Pearl River Delta (PRD) region, J. Hazard. Mater., 250-251, 403-411, 2013.

Zheng, J. Y., Zhang, L. J., Che, W. W., Zheng, Z. Y., and Yin, S. S.: A highly resolved temporal and spatial air pollutant emission inventory for the Pearl River Delta region, China and its uncertainty assessment, Atmos. Environ., 43, 5112-5122, 2009.

Zheng, J. Y., Zheng, Z. Y., Yu, Y. F., and Zhong, L. J.: Temporal, spatial characteristics and uncertainty of biogenic VOC emissions in the Pearl River Delta area, Atmos. Environ., 44, 19601969, 2010a.

Zheng, J. Y., Zhong, L. J., Wang, T., Louie, P. K. K., and Li, Z. C.: Ground-level ozone in the Pearl River Delta region: Analysis of data from a recently established regional air quality monitoring network, Atmos. Environ., 44, 814-823, 2010b.

Zhou, G. Y., Guan, L. L., Wei, X. H., Zhang, D. Q., Zhang, Q. M., Yan, J. H., Wen, D. Z., Liu, J. X., Liu, S. G., Huang, Z. L., Kong, G. H., Mo, J. M., and Yu, Q. F.: Litterfall production along successional and altitudinal gradients of subtropical monsoon evergreen broadleaved forests in Guangdong, China, Plant Ecol., 188, 77-89, 2007. 